\title{
Correction to: $\mathrm{CO}_{2}$ and $\mathrm{SO}_{2}$ emission characteristics of the whole process industry chain of coal processing and utilization in China
}

\author{
Tao Zhu ${ }^{1} \cdot$ Ruonan Wang ${ }^{1} \cdot{\text { Nengjing } \mathrm{Yi}^{1} \cdot \text { Wenfeng Niu }}^{1} \cdot \operatorname{Lifeng}_{\mathrm{Wang}^{1}} \cdot$ \\ Zeyu Xue ${ }^{1}$
}

Published online: 9 January 2021

(C) The Author(s) 2021

\section{Correction to: \\ Int J Coal Sci Technol (2020) 7(1):19-25 \\ https://doi.org/10.1007/s40789-020-00297-1}

In the original publication, there were few amendments to be made:

In Abstract, "4,844,500 tons" should be changed into "4.4845 million tons".

The ordinate unit of Fig. 1 "million tons" should be changed into "billion tons".

In Introduction Section, "China's total coal production increased from 2.57 million tons in 2006 to 3.52 million tons in 2017." should be changed into "China's total coal production increased from 2.57 billion tons in 2006 to 3.52 billion tons in 2017."

In the first sub-Conclusion, " $\mathrm{SO}_{2}$ The emission is 44845 tons" should be changed into " $\mathrm{SO}_{2}$ emissions were 4.4845 million tons".
In the second sub-Conclusion, "34.42 million tons" should be changed into " 34,420 tons", " 0.644 million tons" should be changed into "6440 tons", "27.36 million tons" should be changed into " 273,600 tons", " $170,266,000$ tons" should be changed into "1,702,660,000 tons", "0.012 million. Ton" should be changed into " 212 tons".

Open Access This article is licensed under a Creative Commons Attribution 4.0 International License, which permits use, sharing, adaptation, distribution and reproduction in any medium or format, as long as you give appropriate credit to the original author(s) and the source, provide a link to the Creative Commons licence, and indicate if changes were made. The images or other third party material in this article are included in the article's Creative Commons licence, unless indicated otherwise in a credit line to the material. If material is not included in the article's Creative Commons licence and your intended use is not permitted by statutory regulation or exceeds the permitted use, you will need to obtain permission directly from the copyright holder. To view a copy of this licence, visit http://creativecommons. org/licenses/by/4.0/.
The original article can be found online at https://doi.org/10.1007/ s40789-020-00297-1.

Tao Zhu

bamboozt@cumtb.edu.cn

1 China University of Mining and Technology, Beijing 100083, China 